DOI: 10.32089/WBH.PHW.2021.2(276).0009

orcid.org/0000-0002-6830-2502

\title{
Zmienność niezmiennych zasad sztuki wojennej
}

Jacek Lasota, Zasady sztuki wojennej (Warszawa: Bookmarked, 2020), ss. $492 .^{1}$

Pytanie „jak zwyciężać” towarzyszy wodzom od tysięcy lat. Jednak próby stworzenia prostych i niezawodnych recept prowadzących do sukcesu w historii wojskowości zwykle kończyły się bardziej lub mniej efektownymi klęskami - wszakże generałowie zawsze są gotowi do stoczenia poprzednich bitew. Ta nieustająca dynamika i zmienność wojny doprowadziła do powstania sztuki wojennej, która - jak każda sztuka - wymyka się precyzyjnym ramom i naukowym barierom. Jednak tak jak malarstwo czy rzeźba, również wojna kieruje się swoim specyficznym kanonem: zasadami sztuki wojennej. I właśnie o zasadach sztuki wojennej traktuje niemal 500-stronicowa książka płk. dr. hab. Jacka Lasoty. Autor ten od 2008 r. związany był z Akademią Obrony Narodowej, a od 2016 r. Akademią Sztuki Wojennej - obecnie kieruje Zakładem Historii Sztuki Wojennej i Polemologii w Wydziale Wojskowym. Wcześniej - co stanowi raczej wyjątek niż regułę wśród pisarzy zajmujących się historią sztuki wojennej lub wojskowością - zdobywał doświadczenie w „linii” - m.in. w 6 i 34 Brygadzie Kawalerii Pancernej oraz VIII zmianie Polskiego Kontyngentu Wojskowego Irak. Autor zna więc sztukę wojenną nie tylko z podręczników czy opracowań, ale również z własnych doświadczeń i praktyki dowódczo-sztabowej (z których w tej książce korzysta przy analizie operacji Black Eagle z 2007 r.).

Zasady sztuki wojennej zostały wydane w 2020 r. nakładem Wydawnictwa Bookmarked, które dopiero niedawno pojawiło się na rynku wydawniczym, ale już teraz można zauważyć, że chce się specjalizować w literaturze dotyczącej szeroko pojętego bezpieczeństwa. Książka Jacka Lasoty podzielona jest na trzy główne części: 1. „Założenia teoretyczne zasad sztuki wojennej”, 2. „Poglądy

\footnotetext{
Ponieważ recenzent od kilku lat zna osobiście Autora (którego był nawet studentem w Akademii Obrony Narodowej), czuje się w obowiązku oświadczyć, iż w związku z przygotowaniem niniejszej recenzji nie wystąpił konflikt interesów.
} 
wybranych teoretyków i dowódców na zasady sztuki wojennej” i 3. „Zasady sztuki wojennej w przykładach $\mathrm{z}$ historii wojen”. Opatrzona jest wstępem, zakończeniem, bibliografią oraz załącznikami, w skład których wchodzą wyszczególnione z wybranych regulaminów i doktryn narodowych zasady sztuki wojennej poszczególnych armii i sojuszy.

We wstępie Autor szeroko nakreśla sytuację problemową oraz przedmiot badań, który został sprecyzowany następująco: „przedmiotem badań [...], będą zasady sztuki wojennej i ich atrybuty na przykładzie wybranych bitew i bojów w historii wojen". 2 Ponadto już we wstępie definiuje, jak sam rozumie zasady sztuki wojennej oraz dokonuje skróconej (choć wystarczającej) analizy literatury w tym zakresie. Jak pisze sam Autor, dzieła dotyczące tej tematyki są nieliczne, a w języku polskim brak jest tłumaczeń klasycznych traktatów autorstwa choćby i Christiny de Pizan, Raimondo Montecuccoliego czy Maurycego Saskiego.

Zasadniczą część książki rozpoczyna rozdział 1 „Założenia teoretyczne zasad sztuki wojennej”. Na 53 stronach autor przedstawił dorobek teoretyczny sztuki wojennej i jej działy (taktykę, sztukę operacyjną i strategię) w myśli wojskowej od starożytności do współczesności. Zawiera on rozważania dotyczące podstawowych definicji sztuki wojennej, strategii, sztuki operacyjnej i taktyki oraz praw wojny i walki zbrojnej. Rozdział ten można traktować jako teoretyczny wstęp do omawianych zagadnień. Autor oparł zawarte w nim rozważania nie tylko na poglądach teoretyków i praktyków sztuki wojennej, ale również na regulaminach wojskowych, leksykonach i encyklopediach wojskowości.

Rozdział drugi: „Poglądy wybranych teoretyków i dowódców na zasady sztuki wojennej” obejmuje skrócone biografie i najważniejsze poglądy na sztukę wojenną 26 wybitnych wojskowych. Rozdział podzielony jest na pięć chronologicznie ułożonych części: starożytność, nowożytność, XIX w. oraz pierwszą i drugą połowę XX w.

Kolejny, trzeci rozdział stanowi główną część całej pozycji. Jego treścią są rozważania poświęcone kluczowym - zdaniem autora - zasadom sztuki wojennej w poszczególnych bitwach i bojach od starożytności aż do XXI w. Posługując się przykładami 25 historycznych starć, Lasota stosuje ciekawą metodę historyczno-wojskową, w centrum której stoją zasady sztuki wojennej. Opis każdej bitwy (boju) poprzedzony został zakreśleniem szerszego tła historycznego, przebiegu starcia oraz podsumowania $\mathrm{z}$ wyróżnieniem kluczowych wg autora zasad sztuki wojennej będących fundamentem zwycięstwa. Ponadto przy każdej bitwie (boju) Lasota w formie przystępnej tabeli wskazuje zasady zastosowane zarówno przez stronę zwycięską, jak i przegraną.

2 Jacek Lasota, Zasady sztuki wojennej (Warszawa: Bookmarked, 2020), 8. 
Całość dzieła zamyka krótkie, siedmiostronicowe zakończenie, w którym autor pokusił się o wskazanie najważniejszych zasad sztuki wojennej na współczesnym polu bitwy, do których zaliczył: celowość działań, zaskoczenie, koncentrację wysiłku, jedność dowodzenia, prostotę, swobodę działania i aktywność. Ponadto książka opatrzona została załącznikami, na które składają się zbiory zasad sztuki wojennej z polskich regulaminów i dokumentów doktrynalnych oraz kanony wyszczególniane przez siły zbrojne USA, Wielkiej Brytanii, Francji, Izraela, ZSRS/Federacji Rosyjskiej, Indii, Chin oraz NATO.

Z perspektywy czytelnika najważniejszą cechą Zasad sztuki wojennej jest to, że - wbrew pozorom - nie jest to książka ani historyczna, ani historyczno-wojskowa. Autor używa historii wojskowej jako narzędzia do wyjaśnienia istoty zasad sztuki wojennej, a nie celu samego w sobie. I to jest zdecydowanie największa zaleta tej pozycji, która przez to nabiera niemalże podręcznikowego charakteru. Autor nie koncentruje się na szczegółach nieistotnych dla całości sprawy - ale patrzy na wojnę z szerokiej perspektywy wychodzącej poza taktykę i sztukę operacyjną. Oprócz poglądów wybranych teoretyków w kwestii zasad sztuki wojennej (m.in. Sun Tzu, Ksenofonta, Jana Tarnowskiego, Carla von Clausewitza, Antoine-Henri de Jomini, Heinza Guderiana, Michaiła Tuchaczewskiego, Władysława Sikorskiego, Stanisława Kozieja i wielu innych) czytelnik może na jasno i przejrzyście opisanych przykładach zrozumieć istotę użycia poszczególnych zasad. Oprócz tego, przy opisie każdej bitwy Autor wyszczególnia najważniejsze jego zdaniem zasady użyte przez stronę zwycięską i przegraną, tworząc przy tym „klucz do zwycięstwa”, który dowódca zastosował, by wygrać. Dla przykładu Mieszko I pod Cedynią oprócz tego, że „sztuką zwyciężył”, to użył następujących zasad sztuki wojennej: zaskoczenia, manewru, ekonomii sił, celowości działań, prostoty i współdziałania. Posługując się 25 historycznymi przykładami (od bitwy pod Kadesz, poprzez Cedynię, Obertyn, Bobrujsk, Mokrą, Bzurę, aż do operacji „Płynny Ołów” i „Czarny Orzeł”), Autor omawia wszystkie zasady sztuki wojennej, odnosząc je przy tym do ogólnego tła operacyjnego poszczególnych starć. Po 1989 r. polski czytelnik nie miał okazji przeczytać takiego wywodu - Lasota jako pierwszy dał mu taką szansę.

Jako polemikę z Autorem wysunąć można argument pominięcia $\mathrm{w}$ doborze omawianych teoretyków późnego antyku i średniowiecza. Pomiędzy opisywanymi przez autora „Italczykami” - Juliuszem Cezarem i Niccolo Machiavellim - dostrzec można ponad 1500-letnią wyrwę. Można byłoby zapełnić choćby i dostępnym w polskim tłumaczeniu dziełem Wegecjusza O sztuce wojskowej czy autorami bizantyjskimi: Maurycym i jego Strategikonem lub traktatem Tactica cesarza Leona VI. Nie jest to jednak zarzut - prawem Autora był subiektywny dobór treści. I choć powołanie się na wymienionych powyżej teoretyków ubogaciłoby książkę, to wątpić należy, czy zmieniłoby w jakikolwiek sposób wnioski końcowe. 
Warto również podkreślić, że Autor szczególny nacisk kładzie na rodzimy dorobek w zakresie wojskowości - trzecia część wybranych teoretyków to Polacy. Z perspektywy czytelnika wojskowego jest to dobre posunięcie, choć cywile mogą być nieco mniej usatysfakcjonowani skoncentrowaniem się na ojczystej sztuce wojennej. Przybliżenie poglądów oraz praktycznych rozwiązań postulowanych przez polskich teoretyków, dotyczących naszego obszaru operacyjnego, może być świetną lekcją dla oficerów współczesnego Wojska Polskiego. Wartość tę podnosi również opisanie przez autora 11 starć stoczonych w Europie Środkowo-Wschodniej (od Cedyni poprzez Legnicę, Grunwald, Obertyn, Kircholm, Bobrujsk, aż do boju pod Mokrą i bitwy nad Bzurą). Wskazanie zasad sztuki wojennej decydujących o zwycięstwie w tych starciach również może być przedmiotem analizy współczesnych Sił Zbrojnych RP.

$\mathrm{Z}$ perspektywy zwykłego czytelnika, niezwiązanego $\mathrm{z}$ wojskiem, koncentracja na czytelniku „mundurowym” jest zauważalna. Świadczy o tym język używany przez Autora, sztywne trzymanie się terminologii wojskowej oraz (zapowiadane przez Autora) omijanie szczegółów historycznych przy koncentrowaniu się na kwestiach wojskowych. Warto podkreślić, że Autor nie uległ przy tym pokusie „uelitarnienia” swojej książki poprzez zastosowanie zbyt fachowego, a przez to niezrozumiałego dla ogółu języka wojskowego, a tam, gdzie terminologia ta pojawia się, jest ona niezbędna. Zasady są więc nie tylko podręcznikowym vademecum dla oficerów Wojska Polskiego, ale również świetną pozycją dla miłośników sztuki wojennej wywodzących się ze środowiska cywilnego.

Cech charakteru „podręcznikowego" dodaje również stały i konsekwentnie realizowany układ omawianych treści. W przypadku teoretyków wojskowości wygląda on następująco: krótka biografia, omówienie najważniejszego dzieła oraz podkreślenie i omówienie zasad sztuki wojennej wyróżnionych przez danego teoretyka. Ponadto w każdym przypadku autor zadbał o elementy graficzne, które uatrakcyjniają odbiór. Są to wizerunki (portrety, zdjęcia itd.) teoretyka oraz rysunki podkreślające jego najważniejsze poglądy na zasady sztuki wojennej. W trzeciej części poświęconej omówieniu wybranych bitew układ treści został zaprojektowany przez Lasotę w następujący sposób: tło bitwy, ugrupowanie bojowe przeciwników, przebieg bitwy z podziałem na fazy, przyczyny klęski i zwycięstwa, wyróżnienie zasad sztuki wojennej stanowiącej „klucz do zwycięstwa”, a ostatnim elementem jest autorska argumentacja przemawiająca za takim doborem. Ponadto każde omawiane starcie zostało opatrzone mapą lub szkicem, choć nie zawsze przygotowanym w tej samej konwencji. Z perspektywy czytelnika układ ten się sprawdza - jest dobrze pomyślany i logiczny. Dużym plusem jest też konsekwencja $\mathrm{w}$ stosowaniu przyjętego przez autora schematu.

Głównym elementem książki, na który należy zwrócić uwagę, są autorskie próby wyjaśnienia powodów zwycięstw w omawianych bitwach 
- Lasota ujął je w tzw. „kluczu do zwycięstwa”, który każdorazowo rozpoczyna analizę danego starcia. Pomysł sam w sobie jest bardzo dobry - może być wstępem do pogłębionej o inne czynniki próby wyjaśnienia kto i dlaczego zwycięża w poszczególnych bitwach. Dla przykładu - w bitwie pod Omdurmanem z 1898 r. Lasota za klucz do zwycięstwa uważa zastosowanie: ekonomii sił, celowości działań, jedności dowodzenia i synergię. ${ }^{3}$ Autor na kolejnych stronach dokładnie wyjaśnia i argumentuje swój wybór. Celowość działań objawiła się - zdaniem autora - po stronie brytyjskiej podporządkowaniem wszystkich działań celowi głównemu: odzyskaniu kontroli nad Sudanem poprzez całkowite zniszczenie armii mahdystów, np. poprzez zniwelowanie strategicznej przewagi przeciwnika dzięki wybudowaniu niezwykle drogiej, dofrontowej linii kolejowej służącej zaopatrywaniu wojsk brytyjskich. Ekonomię sił w działaniu brytyjskiego dowódcy Horatio H. Kitchenera Autor zauważa w „racjonalnym, co do realizacji celu bitwy, ugrupowaniu bojowym oraz terminowym zaopatrywaniu i zabezpieczeniu wojsk". ${ }^{4}$ Zasada jedności dowodzenia realizowana była poprzez nieprzerwane kontrolowanie sytuacji na polu walki przez Kitchenera, który wpływał swoimi rozkazami na przebieg bitwy. Natomiast zasada synergii została zrealizowana poprzez współdziałanie ogniowe brytyjskiej artylerii, karabinów i karabinów maszynowych oraz we współdziałaniu poszczególnych oddziałów i pododdziałów brytyjskich przed i podczas bitwy.

Książka wystawia dobre świadectwo wydawnictwu Bookmarked - jest przygotowana starannie, choć są elementy, w których można dostrzec brak doświadczenia tej młodej oficyny. Jednym z nich jest brak jednolitości map. Nie jest to zarzut dyskwalifikujący jakiekolwiek dzieło, ale w przypadku opisywania zasad sztuki wojennej zasadnym wydaje się stworzenie poglądowych szkiców każdego starcia, które ułatwią zobrazowanie czytelnikowi ich roli. Pośród kilkudziesięciu map zamieszczonych w książce trudno znaleźć kilka stworzonych w tej samej konwencji. W tej kwestii wydawca powinien jednak poświęcić nieco więcej czasu i przygotować szkice. Niestety, ale przy niektórych mapach brak jest również legend, co w przypadku starć pod Lutynią i Omdurmanem jest utrudnieniem $w$ dopasowaniu ilustracji do opisywanej sytuacji taktycznej. Zdaniem recenzenta najlepszym wzorem jest rysunek nr 36 obrazujący III fazę bitwy pod Cedynią będący opracowaniem własnym autora. ${ }^{5}$

Mankamentem - zwłaszcza dla czytelników z szeregów SZ RP - jest również forma wydania. Książka wydrukowana została w twardej okładce na papierze kredowym. Czyni to $\mathrm{z}$ tej pozycji elegancki prezent oraz ozdobę

\footnotetext{
Ibid., 348.

Ibid., 349.
}

5 Ibid., 238. 
większości domowych biblioteczek, jednak dyskwalifikuje Zasady sztuki wojennej jako narzędzie pracy oficerów w polu lub podczas ćwiczeń dowódczo-sztabowych. Z pewnością nie można książki tej spakować w plecak lub zabrać do przysłowiowej „kieszeni”, by z jej pomocą przygotować wystąpienie podczas odprawy koordynacyjnej lub decyzyjnej podczas realizowania procesu dowodzenia. Zdaniem recenzenta, w przypadku tej książki, lepsze stało się wrogiem dobrego. Być może dobrym pomysłem byłoby kolejne wydanie pozbawione już tak estetycznego wykończenia lub wprowadzenie do sprzedaży wersji e-book. Ponadto do wad wydawniczych można również zaliczyć drobne potknięcia - literówki i zamiany wyrazów (zamiast korpus armia, itd.). Nie wpływają one jednak w znacznym stopniu na lekturę i wysoką ocenę tej pozycji.

Zasady sztuki wojennej Lasoty są autorską próbą kompleksowego spojrzenia na kwestię zasad sztuki wojennej. Połączenie teorii i praktyki omawianego zagadnienia nie jest częstym przypadkiem we współczesnym piśmiennictwie wojskowym, w którym autorzy koncentrują się albo na teorii, albo na praktyce. Tym samym książka Lasoty stanowi jedną z bardziej udanych, bo kompleksowych pozycji dotyczących sztuki wojennej w ciągu ostatnich lat.

Podsumowując, za najmocniejsze strony Zasad sztuki wojennej można uznać: szeroki wachlarz przykładów historycznych, zwłaszcza z polskiej historii wojskowej, przystępny dla czytelnika język, użycie historii wojskowej jako narzędzia dla wyjaśnienia istoty zasad sztuki wojennej, osadzenie twórczości omawianych teoretyków oraz przebiegu bitew w szerszym kontekście historycznym, stworzenie przez Autora „klucza do zwycięstwa” przy każdej bitwie, szeroka baza źródłowa i bibliograficzna (niemal 800 przypisów i 300 pozycji w bibliografii), stworzenie autorskiego katalogu najważniejszych zasad sztuki wojennej na współczesnym polu bitwy.

Natomiast za wady tej pozycji można uznać: prezentową formę wydania, brak legend przy niektórych mapach oraz ich ograniczoną ilość, drobne potknięcia językowe, a także pominięcie $\mathrm{w}$ treści teoretyków $\mathrm{z}$ późnego antyku oraz wczesnego średniowiecza. Nie bez znaczenia pozostaje również to, że książka napisana została raczej z myślą o czytelniku związanym z siłami zbrojnymi. Pasjonaci historii wojskowości nie znajdą w niej szczegółowych informacji dotyczących poszczególnych, omawianych przez autora, bitew - Lasota traktuje historię jako narzędzie do zarysowania tła dla głównej części swoich rozważań, którą zdecydowanie są zasady sztuki wojennej. Stąd też rzadkością w tej pozycji są fragmenty dotyczące działania na polu walki pododdziałów (szczebel batalionu i niższy). Z jednej strony można więc czuć pewien niedosyt, ponieważ stanowiące znaczną część dzieła charakterystyki bitew są ogólnikowe, a czasami wręcz pobieżne i nie przekraczają 4-5 stron. $Z$ drugiej jednak strony zamysłem Autora z pewnością nie 
było ustalanie pozycji każdej chorągwi pod Grunwaldem czy działa pod Omdurmanem. Stąd też poziom ogólności wywodu i koncentracja na zasadach sztuki wojennej może razić nieco czytelnika nieprzyzwyczajonego do tego typu pisarstwa. Warto jednak podkreślić, że zasada uogólniania tępi się nieco przy opisach bojów toczonych przez wojska pancerne (Flers 1916 i Bobrujsk 1919) - w tych przypadkach Autor z pieczołowitością odtwarza działania nawet plutonów czołgów. Dla entuzjastów broni pancernej to zdecydowanie ogromna zaleta.

Konkludując, należy stwierdzić, że książka Zasady sztuki wojennej autorstwa Jacka Lasoty jest dziełem udanym. Fachowa wiedza Autora oraz ogromny wkład pracy włożony $\mathrm{w}$ powstanie tego opracowania zaowocowały pozycją godną polecenia przede wszystkim oficerom SZ RP. Jednak przystępny, niehermetyczny język oraz zrozumiały, przejrzysty i prosty styl opisywania analizowanych zagadnień otwierają tę pozycję również na czytelników, którzy nie będąc związanymi z siłami zbrojnymi są pasjonatami wojskowości. Przedstawicielom obu tych grup z całą ufnością można pracę tę zarekomendować. Lasota, tworząc tak wszechstronne dzieło zaproponował wzór opisywania historii wojskowej z perspektywy zasad sztuki wojennej. Dla przyszłego wodza nie jest to recepta na odniesienie sukcesu na polu walki i poza nim, jednak lektura i zawarte w niej rozważania nad przeszłością być może pozwolą uniknąć podstawowych błędów w przyszłości.

Michał Przybylak Akademia Sztuki Wojennej 